\title{
Design of EV Charging System by Integrating Renewable Energy Sources with Multiport Converter Modeling
}

\author{
Suvvala Jayaprakash ${ }^{1}$, K. Sathish Kumar ${ }^{2}$ \\ ${ }^{1}$ Vellore Institute of Technology, Vellore, Tamilnadu, India, sjpr20@gmail.com \\ ${ }^{2}$ Vellore Institute of Technology, Vellore, Tamilnadu, India, kansathh21@yahoo.co.in
}

\begin{abstract}
A new architecture of an electric vehicle charging station is proposed in this article. interface between grid to charging stations. The proposed design uses a multiport converter for charging stations by utilizing renewable energy sources. To maintain constant grid voltage/dc link, battery/dc link, and solar voltage bidirectional multiport converters are constructed. In most conditions, solar energy is used to charge the battery and charging stations with high reliability without interrupt gird voltage. Besides, the battery is not used to directly harvest energy from both grid supply and solar supply; thus, the battery is isolated from frequent quick charges, which will increase the life span of the battery. Simulation and experimental results are presented to verify the proposed system using MATLAB
\end{abstract}

Key words: Battery, solar, DC-DC converters, multiport converters, Energy storage, electric vehicles (EVs), Plug-in vehicles, Power electronics Devices.

\section{INTRODUCTION}

Conventional energy sources (fossil fuels) have been exhausted for almost a quarter of a century and are slowly becoming impracticable. With the increased growth of the fossil fuels catastrophe and atmosphere, renewable energy sources such as wind and solar are becoming attractive substitutes. The proportion of renewable energy sources for electricity generation particularly in solar and wind has been enhanced and the growth of solar plants is expected to continue in the future decades.

While traditional modes of transportation, mainly based on internal combustion engines face global advancement pressure to mitigate greenhouse gas emissions such as co2 and alleviate air pollution in urban areas. Electrical vehicles are becoming more attractive than ever, whereas the petroleum era has been extended as a result of the economic growth of shale gas. Over the past 35 years, there have been increasing interest over electric vehicles (EVs). In contrast to the continuity of EV research and improvement in the mid-1960s due to the forwarding concern over air quality and charged over imported petroleum in the 1970s, recent advances in EV have been highly motivated by environmental concerns [1-3].

Motor vehicles are the major cause of air pollutants. For this reason, different commands and legislations have been introduced to electric vehicles into the commercial market. High-performance electric vehicles provide benefits in air and petroleum quality, at a lower cost. Large deployments of EVs in the transportation sector will bring enormous benefits in economic, social, and ecological benefits. Electrical vehicles are a safe and efficient alternative to existing internal combustion engine (ICE) vehicles due to their low acceleration, high cost, and defined range. With the tremendous increase in electric vehicles, so many institutions, companies, and governmental organizations are focusing to design high performance EVs. The commercialization of electric vehicles needs a lot of R\&D work. Apart from battery technology, vehicle propulsion technology is another factor influencing electric vehicle range and efficiency. However, very large and costly batteries are required for achieving a sufficient driving [4].

In electric vehicles (EVs), energy storage systems play a vital role. Apart from different energy storage devices, batteries are the most widely used ones. In battery-based charging stations, the power density of the battery needs to be high enough to meet the peak power demand. batteries with high power densities are typically much larger than lower power density counterparts. To resolve the battery size, cost, and thermal management problems taken as a challenge for batterie to safely work in high power load applications. In order to overcome the above issues, use hybrid energy storage systems (HESS) has been implemented [5].

To control various energy sources to the required energy source it needs efficient converters. Conventional converters have high switching losses and have a large size for high power load applications. To improve the efficiency of the system by using multiport converters. Multiport converters having an advantage of single conversion with multiple input sources as shown in fig.2. Conventional converter structure as 
Suvvala Jayaprakash et al., International Journal of Emerging Trends in Engineering Research, 8(8), August 2020, 4437 - 4442

shown in fig. 1 to interconnect with different energy sources it needs a common DC bus at low voltage and high voltage side.

Table 1: Variations between Multiport and conventional converter structure

\begin{tabular}{|c|c|c|}
\hline & $\begin{array}{l}\text { Conventional } \\
\text { converter }\end{array}$ & $\begin{array}{l}\text { Multiport } \\
\text { converter }\end{array}$ \\
\hline $\begin{array}{l}\text { Conversion } \\
\text { stages }\end{array}$ & $\begin{array}{c}\text { Multiple } \\
\text { conversions }\end{array}$ & $\begin{array}{c}\text { Single } \\
\text { conversion }\end{array}$ \\
\hline $\begin{array}{c}\text { Power flow } \\
\text { management }\end{array}$ & Robust, slow & Simple, fast \\
\hline $\begin{array}{l}\text { Common DC } \\
\text { bus }\end{array}$ & It required & Not required \\
\hline Transformer & Multiple & $\begin{array}{l}\text { Multiwinding } \\
\text { but single }\end{array}$ \\
\hline $\begin{array}{l}\text { Control } \\
\text { system }\end{array}$ & Bisect control & $\begin{array}{l}\text { Centralized } \\
\text { control }\end{array}$ \\
\hline Applications & High & Low \\
\hline
\end{tabular}

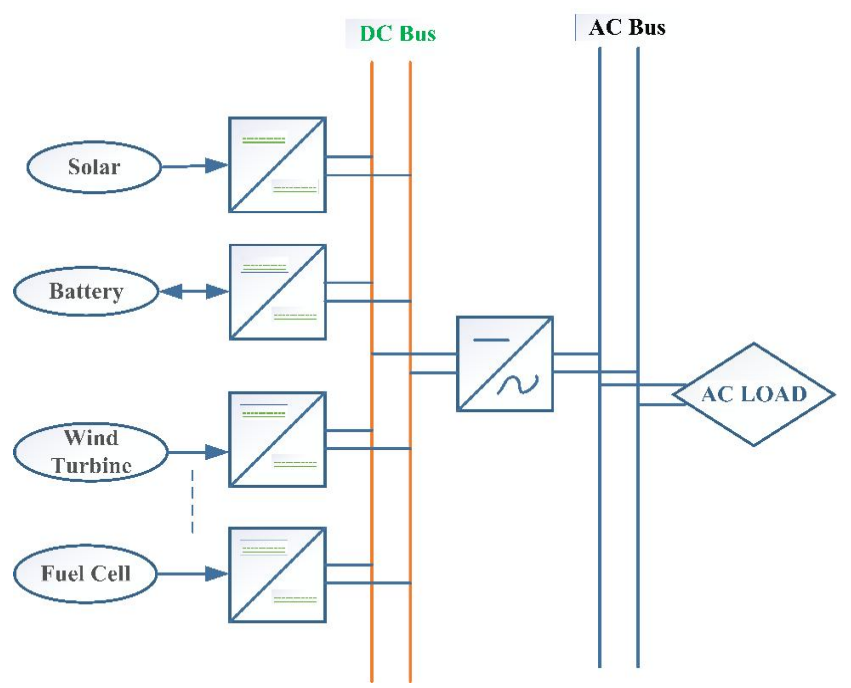

Figure 1: Conventional Converter

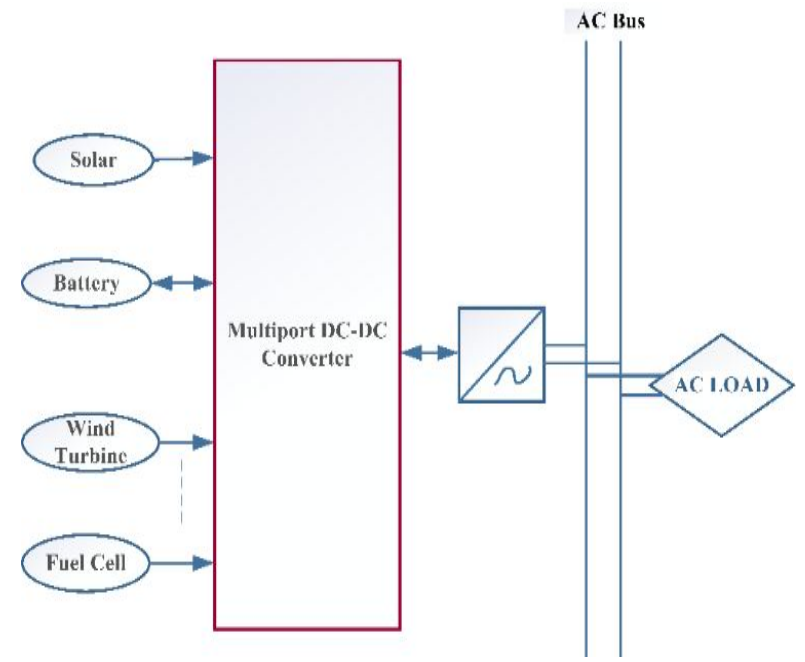

Figure 2: Multiport Converter

\section{DESIGN AND WORKING PRINCIPLE OF SYSTEM}

The three power sources, including PV and EV charger unidirectional sources, and AC grid bi-directional source, are connected through three separate converters in the conventional architecture of the Dc bus charging station, figure. 3 with PV integration. The proposed DC bus charging station shown in Figure. 4, incorporates one more bi-directional power source BES allocated with the same DC bus.

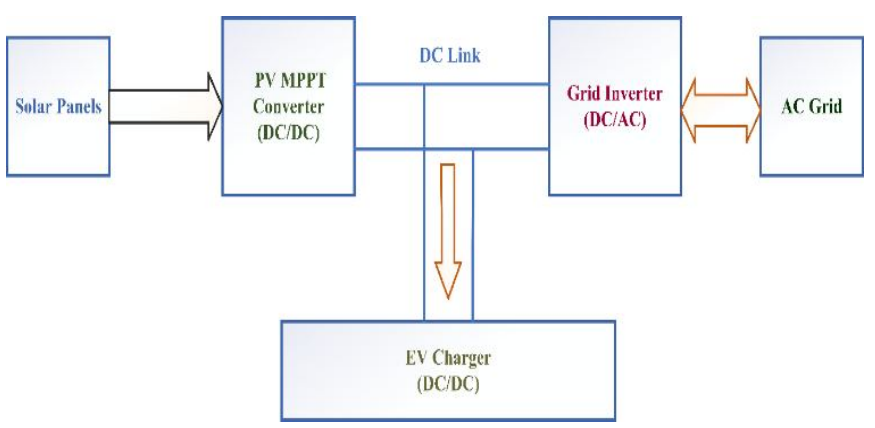

Figure 3: Conventional structure of Solar system with EV charging

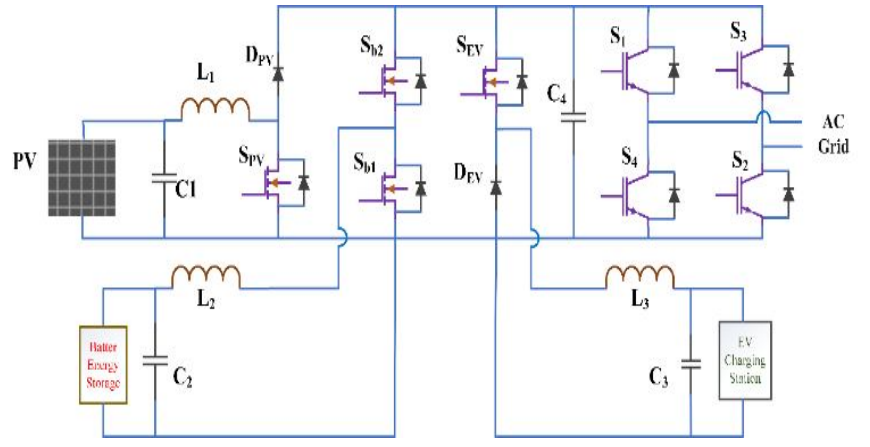

Figure 4: proposed circuit diagram for integration of renewable energy sources with EV charging station.

In this proposed system, it exists various operating modes and the functions can be explained in following sections.

\section{Mode 1: Solar system to EV}

The switches $S_{\mathrm{PV}}, \mathrm{S}_{\mathrm{b} 2}, \mathrm{~S}_{\mathrm{b} 1}$ are turned OFF in this mode, and Switch $\mathrm{S}_{\mathrm{EV}}$ is only switched ON. So, Solar power is directly delivered to the load as shown in figure.5.

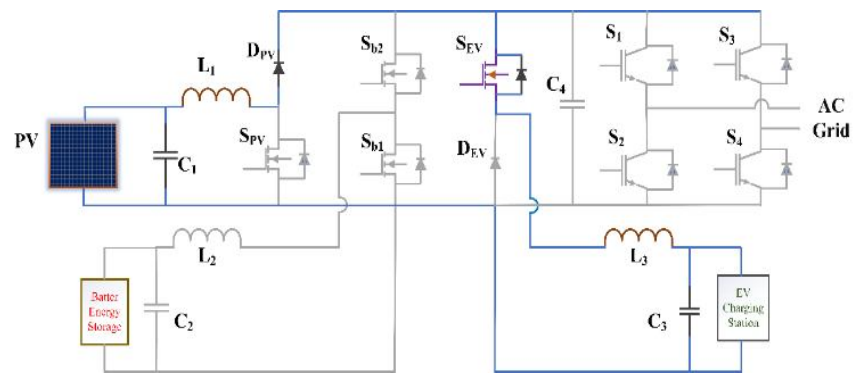


Figure 5: Power flow from Solar to EV charging station

$$
\begin{aligned}
& \mathrm{I}_{p V}=i_{c 1}+i_{s \mathrm{v}} \\
& \mathrm{I}_{e 1}=c_{1}\left(\mathrm{dv} \mathrm{v}_{c} / \mathrm{dt}\right) \\
& \mathrm{I}_{c 2}=c_{2}\left(\mathrm{dv}_{e 2} / \mathrm{dt}\right) \\
& \mathrm{I}_{b a t}=\left(\mathrm{v}_{b a t} / r_{b}\right)=\left(\mathrm{v}_{e 2}-\mathrm{v}_{b a t}\right) / r_{b} \\
& c_{2}\left(\mathrm{dv}_{c 2} / \mathrm{dt}\right)=-i_{L 2^{-}}\left(\mathrm{v}_{b a t^{-}} \mathrm{v}_{c 2}\right) / r_{b} \\
& \mathrm{I}_{\mathrm{wV}}=c_{3}\left(\mathrm{dv} c_{3} / \mathrm{dt}\right)+\left(\mathrm{v}_{\mathrm{ev}} / R_{\mathrm{wv}}\right) \\
& L_{3}\left(\mathrm{dv}_{L 3} / \mathrm{dt}\right)=\mathrm{v}_{e 1}-\mathrm{v}_{e 3} \\
& L_{2}\left(\mathrm{~d} i_{L 2} / \mathrm{dt}\right)=-\mathrm{v}_{c 2}
\end{aligned}
$$

$S_{p v}$ can be operated when solar voltage is greater than grid voltage Vgrid then $S_{F v}$ only can be turned ON $S_{F v}$ duty cycle can be calculated as

$$
\begin{aligned}
& \mathrm{v}_{d e} / \mathrm{v}_{P V}=\left(1 /\left(1-D_{p V}\right)\right) \\
& D_{p V}=\left(1-\left(\mathrm{v}_{p V} / \mathrm{v}_{d e}\right)\right)
\end{aligned}
$$

Where

$\mathrm{C}_{1}=$ Capacitance across Solar port

$\mathrm{C}_{2}=$ Capacitance across the BES port

$\mathrm{C}_{3}=$ Capacitance across the EV port

$\mathrm{L}_{1}=$ Inductance across the Solar port

$\mathrm{L}_{2}=$ Inductance across the BES port

$L_{3}=$ Inductance near the EV load port and

$\eta_{\mathrm{b}}=$ Equivalent resistance of $\nu_{\mathrm{bat}}$ and $c_{2}$

$i_{F v}=$ output current from Solar

$i_{E v}=$ current of EV load

$i_{L z}=$ current flowing through inductor $L_{z}$,

$i_{2 z}=$ current flowing through inductor $L_{3}$

$v_{c 1}, v_{c z}, v_{c z}, v_{k a t}$, and $v_{z v}$ notations for voltage across the capacitor $\mathrm{C}_{1}$, voltage across $\mathrm{C}_{2}$, voltage across $\mathrm{C}_{3}$, BES output voltage and $\mathrm{EV}$ charger voltage respectively.

\section{Mode 2: Battery to EV}

When Switches $S_{\mathrm{PV}}$ and $\mathrm{S}_{\mathrm{EV}}$ are turned $\mathrm{ON}$, remaining switches are turned OFF then power delivers to Battery to load as shown in fig.6. This mode can be existing only when the battery SOC is full and both the solar and grid supply is not available.

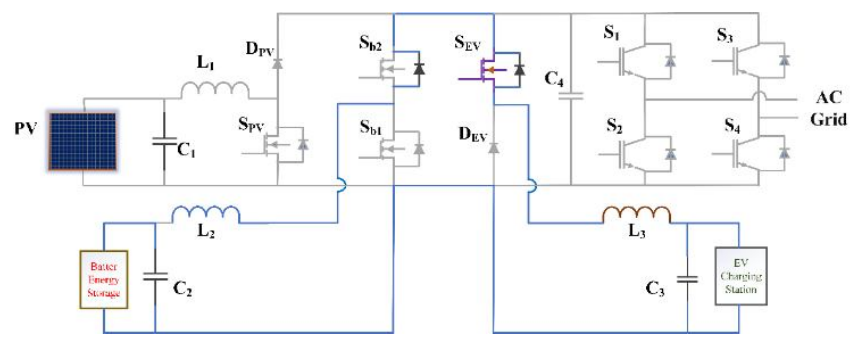

Figure 6: Power flow from battery to EV charging station

The duty cycle of switches can be calculated by using following equations

$$
\begin{aligned}
& \mathrm{I}_{p V}=c_{1}\left(\mathrm{dv}_{e 1} / \mathrm{dt}\right) \\
& \mathrm{L}_{2}\left(\mathrm{di}_{L 2} / \mathrm{dt}\right)=\mathrm{v}_{D c^{-}} \mathrm{v}_{c 2}
\end{aligned}
$$

$$
\begin{aligned}
& \mathrm{v}_{D C}-\mathrm{v}_{C 3}=\mathrm{L}_{\mathrm{B}}\left(\mathrm{di} \mathrm{i}_{\mathrm{L} 3} / \mathrm{dt}\right) \\
& \mathrm{c}_{2}\left(\mathrm{dv}_{\mathrm{c} 2} / \mathrm{dt}\right)=\left(\left(\mathrm{v}_{\mathrm{bat}}-\mathrm{v}_{\mathrm{cz}}\right) / \mathrm{r}_{\mathrm{b}}\right)-\mathrm{i}_{\mathrm{L} 2} \\
& i_{\mathrm{eV}}=\mathrm{c}_{3}\left(\mathrm{dv}_{\mathrm{cB}} / \mathrm{dt}\right)+\left(\mathrm{V}_{\mathrm{EV}} / \mathrm{R}_{E V}\right) \\
& \mathrm{V}_{\mathrm{DC}} / \mathrm{V}_{\text {bat }}=1 /\left(1-\mathrm{D}_{\mathrm{b} 1}\right) \\
& \mathrm{D}_{\mathrm{b} 1}=1-\left(\mathrm{v}_{\mathrm{bat}} / \mathrm{v}_{\mathrm{DC}}\right) \\
& \text { Where } \bar{D}_{b i 1} \text { duty cycle for switch Sb1. }
\end{aligned}
$$

\section{Mode 3: PV to BES}

In this condition the switch $S_{b 2}$ is turn $\mathrm{ON}$, remaining switches $S_{\mathrm{b} 1}, \mathrm{~S}_{\mathrm{PV}}$, and $\mathrm{S}_{\mathrm{EV}}$ are turned OFF. Therefore, the battery is charging from solar supply as shown in fig.7.

By using volt second balance equations calculate the voltage and current across the inductor and voltage.

$$
\begin{aligned}
& \mathrm{I}_{\mathrm{pv}}=\mathrm{c}_{1}\left(\mathrm{dv_{ \textrm {c } 1 }} / \mathrm{dt}\right)-\mathrm{i}_{\mathrm{L} 2} \\
& \mathrm{~L}_{2}\left(\mathrm{di}_{\mathrm{L} 2} / \mathrm{dt}\right)=\mathrm{v}_{\mathrm{c} 1}+\mathrm{v}_{\mathrm{DC}}-\mathrm{v}_{\mathrm{c} 2} \\
& \mathrm{~L}_{3}\left(\mathrm{di}_{\mathrm{L} 3} / \mathrm{dt}\right)=\left(\mathrm{v}_{\mathrm{bat}}-\mathrm{v}_{\mathrm{c} 2}\right) / \mathrm{r}_{\mathrm{b}}-\mathrm{i}_{\mathrm{L} 2} \\
& \mathrm{I}_{\mathrm{EV}}=\mathrm{c}_{3}\left(\mathrm{dv} \mathrm{v}_{\mathrm{c} 3} / \mathrm{dt}\right)+\mathrm{v}_{\mathrm{EV}} / \mathrm{R}_{\mathrm{EV}}
\end{aligned}
$$

Switching pulses for $\mathrm{S}_{\mathrm{b} 2}$ can be calculated by using given equation

$$
\mathrm{v}_{\mathrm{hat}} / \mathrm{v}_{\mathrm{nc}}=\mathrm{D}_{\mathrm{h} 2}
$$

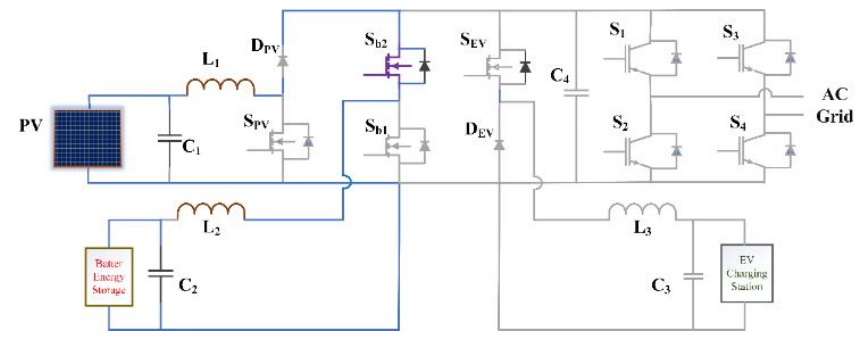

Figure 7: Power flow Solar system to Battery energy storage device

\section{Mode 4: Grid to EV}

$\mathrm{S}_{\mathrm{EV}}$ is in $\mathrm{ON}$, remaining switches $\mathrm{S}_{\mathrm{PV}}$ is in OFF, $\mathrm{S}_{\mathrm{b} 1}, \mathrm{~S}_{\mathrm{b} 2}$ are in $\mathrm{ON} / \mathrm{OFF}, \mathrm{OFF} / \mathrm{ON}$ condition then grid supplies the power to the EV charging station as shown in fig.8. This mode can be existing when the solar and battery supply is shortage.

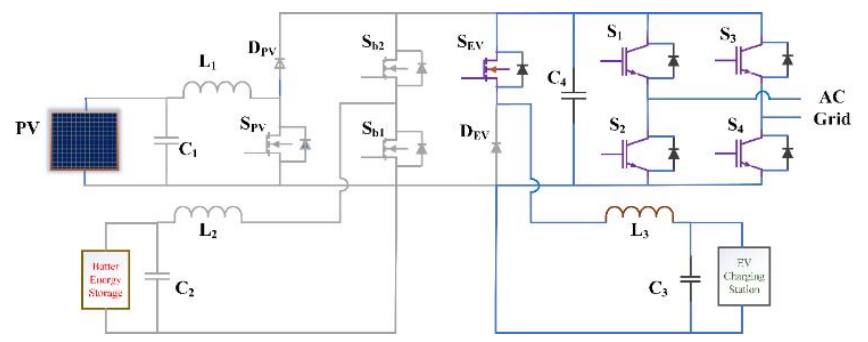

Figure 8: Grid to EV charging station power flow architecture 


\section{Mode 5: Solar to Grid}

When the battery SOC is $100 \%$, EV charging is in idle condition at the same time solar generates excess power then only the solar energy can be delivers to the grid system as shown in fig.9. Grid side converter can be operated as bidirectional converter using novel control strategy.

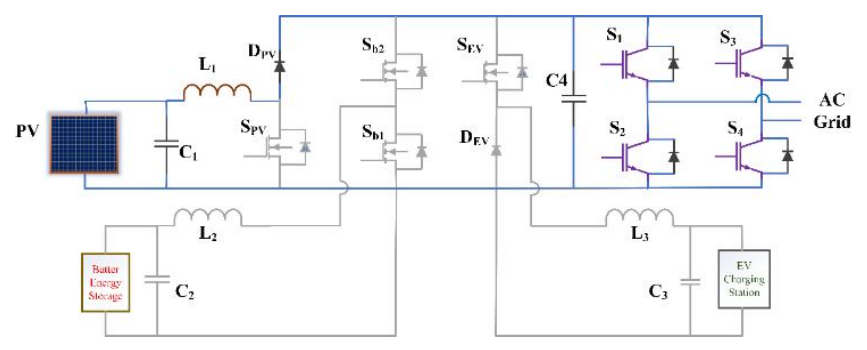

Figure 9: Power flow architecture of Solar to Grid

\section{CONTROL TECHNIQUES AND SIMULINK SPECIFICATIONS}

To design the proposed EV charging station modes and function schemes, using following Structure in Fig.4 is simulated by MATLAB. The mat lab simulation circuit diagram as shown in fig.10. The Solar cell array is designed with Suntech STP235-20-Wd [7], with 5 cascaded strings and 14 strings in series. The open circuit Solar cell array can be modelled to with stand a supplies $16 \mathrm{~kW}, 500 \mathrm{~V}$ to supply the Charging station with constant DC voltage.

When the solar available with sufficient amount, the solar cells can be delivering the power to the EV Charging station. If Solar is surplus the Battery will have charged. If solar is not available like partial shading or other intermittent situation, then battery can be discharged, and it can fill the gap between Solar and EV charging station [7]. Isolated converter can be reduced the total harmonic distortion and performed for high-frequency transformer to improve the power factor correction [8]. By using power electronic novel switches like MOSFETs and IGBTs soft switching can be obtained due to soft switching the losses can be optimized and efficiency of the converter is improved [9]. Bi-directional DC-DC converter are used for renewable energy sources with integration of electric drives [10]

The irradiance drops from $1000 \mathrm{k} / \mathrm{W}^{2}$ to $500 \mathrm{k} / \mathrm{W}^{2}$, then at $325 \mathrm{~V}$, the solar cell power drops from $11 \mathrm{~kW}$ to $5.7 \mathrm{~kW}$. At minimum load situation the proposed system can be improved $98.52 \%$ of efficiency for Solar to EV charging mode, which is $5.78 \%$ larger compared with the traditional based converter. Same wise PV to BES is $4.52 \%$ is increased and Battery to EV is $6.432 \%$ is larger than the conventional mode.

The switching cases can be operated by simple logic gates depends on operating modes. The modes can be classified by the DC link voltage, Battery voltage and Solar voltage. If Solar voltage is surplus compared to the DC link voltage then
Grid is in off condition, in this mode the solar can be supply the power to the EV Charging station. However, if EV charging is also in off condition then battery can be charged. In same case if Battery SOC is also 100\% than the solar can delivers the power to the grid.

If Solar is not available, then battery or Grid can be supplying the power to the EV charging station. In this case if battery SOC is less than $25 \%$ then grid can be delivers the power to the Charging station.

Table 2: Different modes of EV Charging

\begin{tabular}{|l|l|l|l|l|}
\hline $\mathrm{S}_{\mathrm{pv}}$ & $\mathrm{S}_{\mathrm{b} 1}$ & $\mathrm{~S}_{\mathrm{b} 2}$ & $\mathrm{~S}_{\mathrm{EV}}$ & $\begin{array}{l}\text { Powe } \\
\text { r flow }\end{array}$ \\
\hline Open & Open & Close & Open & $\begin{array}{l}\text { Solar } \\
\text { to BES }\end{array}$ \\
\hline Open & Open & Open & Open & $\begin{array}{l}\text { Solar } \\
\text { to } \\
\text { Grid }\end{array}$ \\
\hline Open & Open & Open & $\begin{array}{l}\text { Clos } \\
\epsilon\end{array}$ & $\begin{array}{l}\text { Solar } \\
\text { to EV }\end{array}$ \\
\hline $\begin{array}{l}\text { Clos } \\
\mathrm{e}\end{array}$ & Open & Open & $\begin{array}{l}\text { Clos } \\
\epsilon\end{array}$ & $\begin{array}{l}\text { BESto } \\
\text { EV }\end{array}$ \\
\hline- & $\begin{array}{l}\text { Close/ Ope } \\
\mathrm{n}\end{array}$ & $\begin{array}{l}\text { Open/ Clos } \\
\epsilon\end{array}$ & $\begin{array}{l}\text { Clos } \\
\epsilon\end{array}$ & $\begin{array}{l}\text { Grid } \\
\text { to EV }\end{array}$ \\
\hline
\end{tabular}

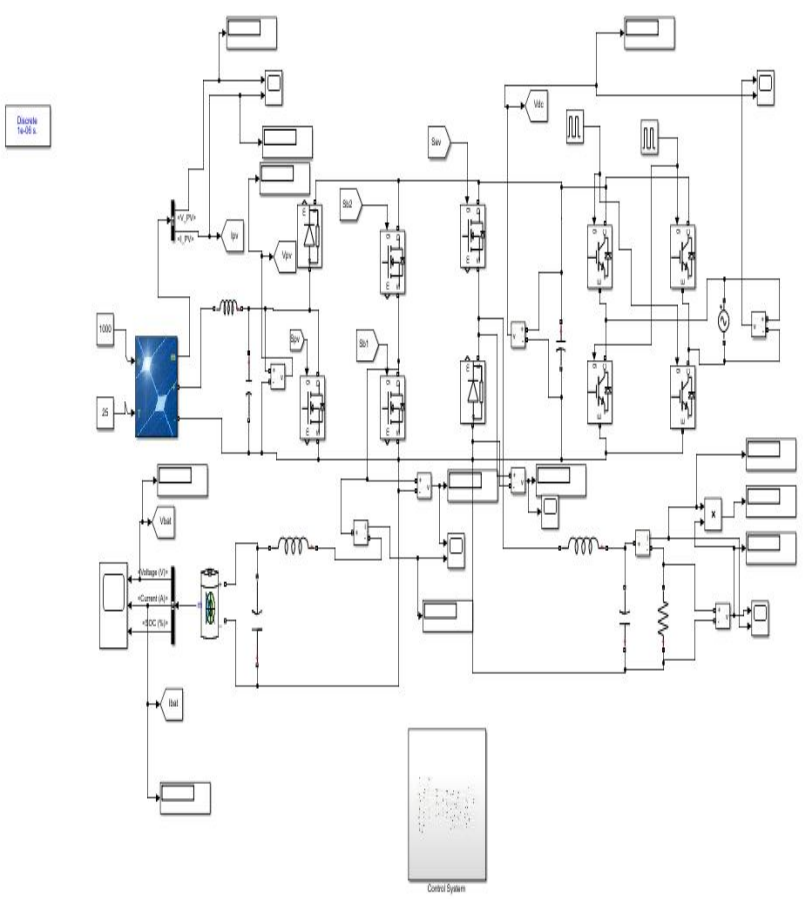

Figure 10: The proposed Simulink diagram for integration of renewable energies 


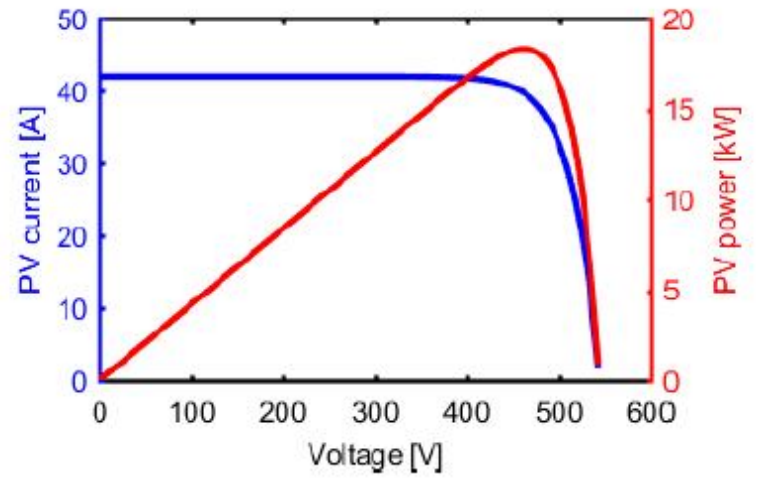

4. WAVEFORMS AND RESULTS

Figure 11: P-V and I-V characteristics of Solar cells at the time of irradiance decreases from 1000 to $500 \mathrm{~W} / \mathrm{m}^{2}$

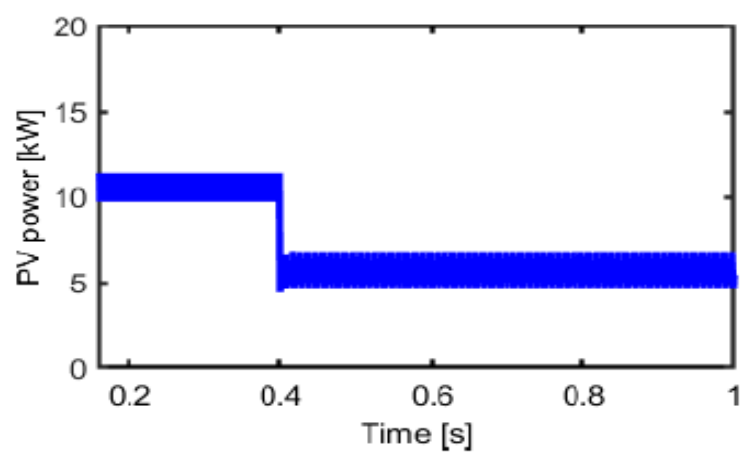

Figure 12: Output power of the Solar system

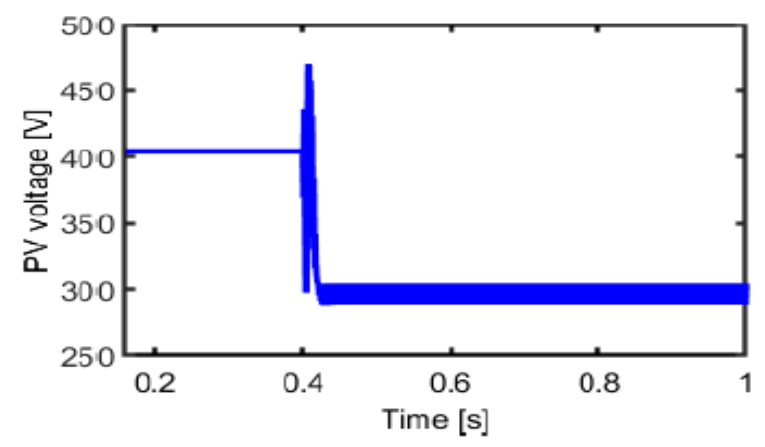

Figure 13: Output Voltage of the Solar system

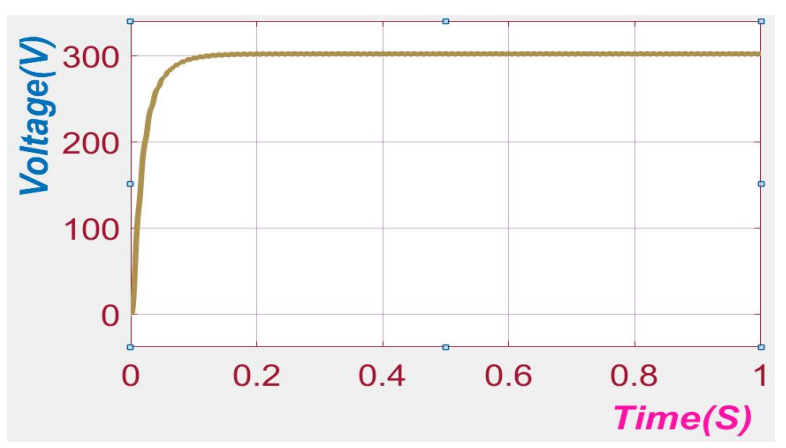

Figure 14: Output voltage of the EV charging station

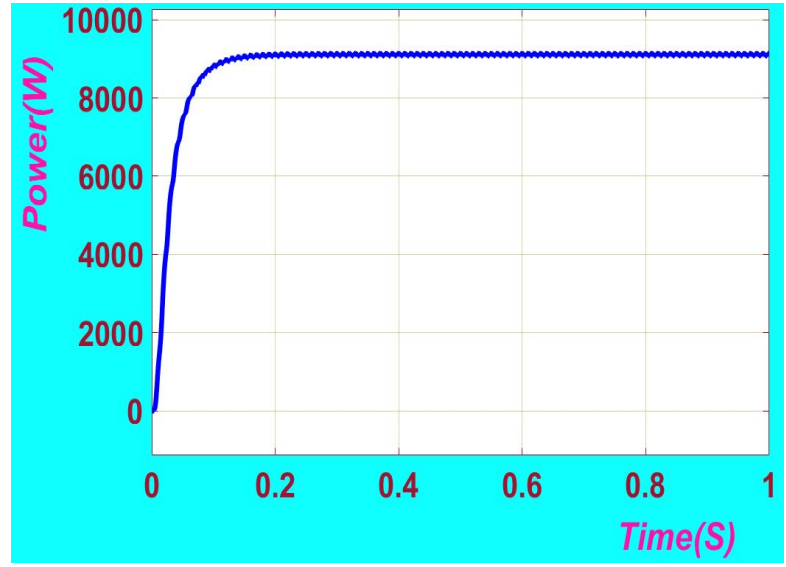

Figure 15: Output power of the EV charging station

\section{CONCLUSION}

In this research paper, EV charging station is integrated with renewable sources with effective multiport converter is designed. The Battery energy storage controller was designed to control the unbalanced voltage levels and it improves the power gap between charging station and Solar system. In this design different modes of operation have explained based on availability of renewable sources. Battery can be charged when the solar is surplus generation when grid is in low demand, therefore at night time. It enhances the Stability and reliability of the power grid by integrating with solar system, battery and EV charging. Because of the multiport converter the overall system improves with an efficiency of $5.78 \%, 4.52 \%$ and $6.432 \%$ respectively, for Solar to EV, Solar to Battery and Battery to $\mathrm{EV}$ at nominal working conditions.

\section{REFERENCES}

[1]. A.F. Burke, "Electric Vehicle Propulsion and Battery Technology 1975-1995”. Proc. Of IECEC, 1990, pp.119-135.

[2]. M. DeLuchi, Q. Wang and Q. Sperling, "Electric Vehicles: Performance, Life-Cycle Costs, Emissions, and Recharging Requirements". Transportation Research-A, Vol. 23A, No. 3, 1989, pp. 255-278.

[3]. L. Chang, "Recent Developments of Electric Vehicles and Their Propulsion Systems," IEEE Aerospace and Electronic Systems Society Systems Magmine, Vol. 8, No. 12, Dec. 1993, pp.3-6.

[4]. Chang L. "Comparison of AC drives for electric vehicles-a report on experts' opinion survey". IEEE Aerospace and Electronic Systems Magazine. 1994 Aug;9(8):7-11.

[5]. Cao J, Emadi A. "A new battery/ultracapacitor hybrid energy storage system for electric, hybrid, and plug-in hybrid electric vehicles". IEEE Transactions on power electronics. 2011 May 
5;27(1):122-32.

[6]. Tao H, Kotsopoulos A, Duarte JL, Hendrix MA. "Family of multiport bidirectional DC-DC converters". IEE Proceedings-Electric Power Applications. 2006 May 1;153(3):451-8.

[7]. Zhang Y, He J, Ionel DM. "Modeling and Control of a Multiport Converter based EV Charging Station with PV and Battery". In2019 IEEE Transportation Electrification Conference and Expo (ITEC) 2019 Jun 19 (pp. 1-5). IEEE.

[8]. Reddy, Nagi. (2020). "Design of a Novel Isolated Single Switch AC/DC Integrated Converter for SMPS Applications". International Journal of Emerging Trends in Engineering Research. 8. 1111-1119. 10.30534/ijeter/2020/26842020.

[9]. Ramalingam, Elavarasu. (2020). "A Soft-Switched Bi-directional DC-DC Converter for a BLDC motor based Electric Vehicle". 10.30534/ijeter/2020/11862020.

[10]. R.Kh, Kurmaev. (2020). "Conceptual Test Rig for Real-Time Analysis of Operation of Thermostatic System of High-Voltage". International Journal of Emerging Trends in Engineering Research. 8. 1208-1211. 10.30534/ijeter/2020/42842020. 